\title{
耳下腺腫瘍の内部エコーヒストグラムの検討
}

\author{
緒方 洋一・浦 正子・今手 祐二 \\ 木戸 利成・田原 哲也
}

\section{Evaluation of Internal Echo Histograms of Parotid Gland Tumors}

\author{
Yoichi Ogata, Masako Miura, Yuji Imate, \\ Toshishige Kido and Tetsuya Tahara \\ (Yamaguchi University)
}

\begin{abstract}
In order to obtain a cue for the differential diagnosis, we evaluated the internal echo histograms of 15 parotid gland tumors (12 benign, 3 malignant) with respect to standard deviation (SD) of the echo level and width of histograms at $0 \%, 25 \%, 50 \%, 75 \%$ frequency.

1) The average $\mathrm{SD}$ of the echo level of malignant tumors was 8.43 , which was significantly greater than that of benign tumors $(\mathrm{p}<0.05)$.

2) An analysis of the width of the histograms showed three patterns: bell type for malignant tumors, mountain type with a wide base for benign tumors and mountain type with a narrow base for normal parotid glands.

It is concluded that we can obtain objective information from the SD of the echo levels and the width of histograms for the differential diagnosis of parotid gland tumors.
\end{abstract}

Key words: parotid gland tumor, internal echo histogram, standard deviation, width of histogram

はじめに

耳下腺腫瘍の組織像は多彩であるため，術前 に良性・悪性の診断を得ることは治療方針決定 に際し，有用な情報になる．

従来より耳下腺腫瘍の超音波診断基準が提唱 されているものの1) 3), 最近では高分解能診断 装置が普及し, より詳細な内部構造が描出され るため, 単に均一, 不均一と判定し難い症例に 遭遇することも少なくない4).

そこで我々は超音波画像のヒストグラムを用 い, エコー強度の分布の様子を定量的に数值化
し，内部エコーパターンのより客観的な表現を 試みている。エコーレベルの標準偏差 (SD) 抒 よびヒストグラム幅について比較検討し, 頭頸 部腫瘤に対する良性・悪性鑑別について報告し てきた5)6)が，今回は耳下腺腫瘍のみを対象と した内部ェコーヒストグラムの比較検討を行い, 良性・悪性の鑑別について検討した.

\section{対 象}

山口大学医学部附属病院で超音波検査を施行 し, 病理組織診断を得た耳下腺腫瘍 15 症例を対 象とした．表 1 のごとく，良性腫瘍 12 例，悪性 
腫瘍 3 例である。

輬胞を形成しているもの，それに類似の囊胞 状エコーを含む腫瘍および石灰化を伴う腫瘍は 全て除外し，超音波画面上で充実性の腫痬と考 えられたもののみを対象とした。

\section{方法}

使用機器は Aloka SSD-630, 7.5 MHz セクタ スキャナである. Gain は80 設定し，STC (sensitivity time control) は全て一定とした. 関心領域は腫瘍をトレースして設定し，ヒスト グラムを作製, 標準偏差およびヒストグラム幅 を測定した。尚, 標準偏差は得られたヒストグ ラムより内蔵のコンピュータで処理, 算出され たものを用いた。ヒストグラム幅は $0 \% ， 25 \%$ ， 50\%，75\%頻度に执けるそれぞれのェコーレベ ルの幅を計測した。

\section{結果}

1 ）エコーレベルの標準偏差について

良性腫瘍, 悪性腫瘍別に得られたヒストグラ ムのエコーレベルから標準偏差を求め, プロッ トしたものを図 1 に示した。 な拉，正常耳下腺 群として，健常者10名の耳下腺に対し，同様に 標準偏差を計測した。

悪性腫瘍の標準偏差は平均 8.43 , 良性腫瘍は 平均7.49 と, 悪性腫瘍は良性腫瘍に比べて $5 \%$ の危険率で有意に大きな值となった．悪性腫瘍 の内部エコーレベルは良性腫瘍に比べて, 散ら ばりがある，つまり不均一である可能性が示唆 された。

表 1 対 象 今回検討した耳下腺腫瘍15例の病理組織学的分類

\begin{tabular}{ll|ll}
\hline \hline \multicolumn{2}{c|}{ 良性 腫 瘍 } & \multicolumn{2}{c}{ 覀性 腫 瘍 } \\
\hline 多型腺腫 & 6 & 粘表皮腫瘍 & 2 \\
腺リンパ腫 & 4 & 腺様襄胞癌 & 1 \\
単一型腺腫 & 1 & & \\
神経鞘腫 & 1 & & \\
\hline & 計12例 & & 計 3 例
\end{tabular}

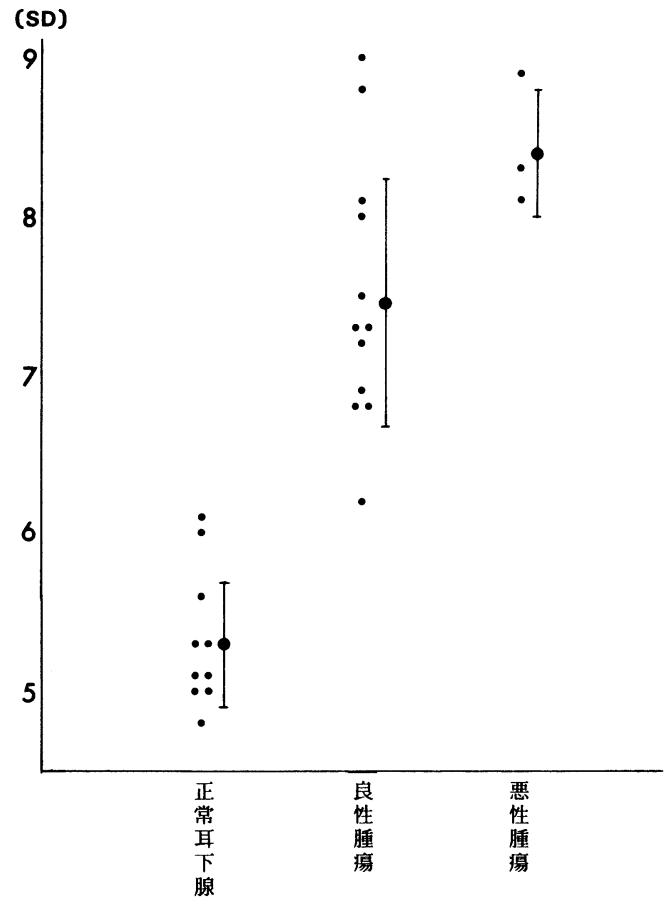

図 1 エコーレベルの標準偏差 (SD) の比較 悪性腫瘍の標準偏差は良性腫瘍と比べて, 有意に 大きな值を示した $(\mathrm{p}<0.05)$.

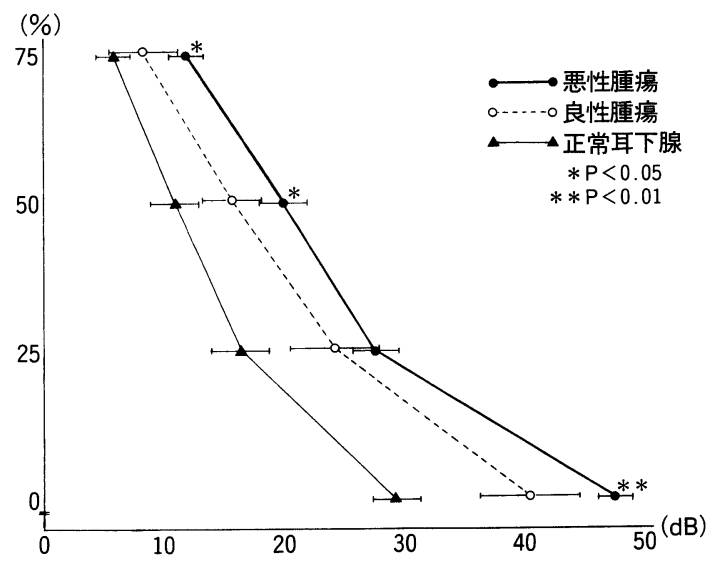

図 2 ヒストグラム幅の比較 悪性腫瘍, 良性腫瘍, 正常耳下腺組織別に得られ たヒストグラムの $0 \% ， 25 \% ， 50 \% ， 75 \%$ 頻度に おけるェコーレベル幅の平均值をプロットした。 25\%頻度に拈いてのみ有意差がないが，その他全 ての\%頻度に扣いて，悪性腫痬は良性腫瘍よりも 有意に幅の広いヒストグラムを形成する。 
2 ）ヒストグラム幅について

悪性腫瘍, 良性腫瘍, 正常耳下腺別に得られ たヒストグラムの $0 \% ， 25 \% ， 50 \% ， 75 \%$ 頻度 に拉けるェューレベルの幅を図 2 に示した。

悪性腫瘍と良性腫瘍を比較してみると，25\% 頻度に执いてのみ有意差がないが，その他全て の\%頻度に执いて，悪性腫瘍は良性腫瘍よりも 有意に幅の広いヒストグラムを形成することが 判明した．良性腫瘍のヒストグラムを山型とす れば，悪性腫瘍のそれはさらに幅が広く，丸み を持ったベル型の様なとストグラムを形成する であろうと考えられた。

\section{考察}

頭頸部腫瘍の組織像は極めて多彩で，かつそ の発生母地により特殊性がある。たとえば，耳 下腺腫瘍と甲状腺腫瘍とでは, 術前に予想され る組織像は大きく異なり，その超音波画像も必 然的に違ってくる.

前回までの報告5)6) では，異なる臓器に発生 した腫瘍をひとまとめにし，頭頸部腫瘤として 対象を設定したが，今回は耳下腺腫瘍のみを対 象とし，内部ェューヒストグラムの比較検討を 行った. エコーレベルは絶対的な数值ではなく， エコーレベル自体の比較はできないといら立場 で，比較項目は前回同様エコーレベルの標準偏 差とヒストグラム幅の 2 項目とした.

悪性腫瘍の標準偏差は良性腫瘍のそれより大 きな值を示し， $5 \%$ の危険率で有意差を認めた。 すなわち悪性腫瘍は良性腫瘍より，さむざまな エューレベルを多く含んでいるといらことが言
える.つまり, 描出された腫瘍の内部エコーが 良性腫瘍より不均一であるという可能性が示唆 される。描出画像を見ても, 標準偏差が8.0以 上になると不均一さが目立ってくる．正常耳下 腺組織の標準偏差は平均 5.33 之腫瘍に比べて明 らかに小さく, 腫瘍病変との差はヒストグラム でも明瞭に区別される。

また，ヒストグラム幅については前回の報告 と同様の結果であった。つまり, 悪性腫瘍は裾 野・中腹ともに広いベル型を, 良性腫瘍は裾野 の広い山型を, 正常耳下腺は裙野の狭い山型の ヒストグラムを形成すると考えられた（図 3 ).

良性腫瘍の標準偏差の中で, 腺リンパ腫 $(\mathrm{SD}=9.0)$ と多型腺腫 $(\mathrm{SD}=8.8)$ の 2 例が9.0 前後の高い値を示した. この両者の内部エコー は, 低エコー輝度と高エュー輝度のスポットが 斑なく散らばっているように混在しているため, 超音波画像のイメージとしては均一な内部エ コーと判断でき，超音波画像診断上誤ることは ない、しかし，ヒストグラムとして処理してし まうと, 得られた画像の散らばり具合, 同じレ ベルのエコースポットの癒合具合が加味されず, 標準偏差は大きな值となってしまった。ヒスト グラムは関心領域内にあるピクセルのエコーレ ベルを統計処理して並べ換えたものであり，画 像の不均一性をそのまま表現するものではない． その意味でも従来の超音波診断基準から求めら れる超音波画像のイメージは良性・悪性の鑑別 には必須のものであることに異論はない。しか し，典型例を除いた判断に苦慮する症例におけ
悪性腫瘍

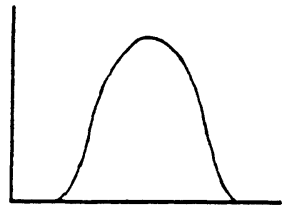

ベル型
良性腫瘍

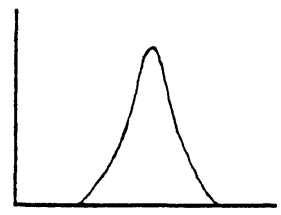

山型

（裾野が広い）
正常耳下腺

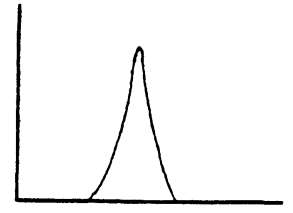

山型

(裾野が狭い)

図 3 ヒストグラムのパターン分類 
る診断や経験的なイメージのパターン認識のた め生じる検者による差をなくすには，客観的な 評価による情報の意義は大きく，ヒストグラム による内部エコー解析が従来の診断基準の補助 診断として大いに活躍するであろう.

\section{まとめ}

1. 耳下腺腫瘍15例から得られた内部ェコー ヒストグラムを標準偏差およびヒストグラム幅 について解析し, それぞれを悪性腫瘍, 良性腫 瘍別に比較検討した上でその鑑別の可能性を考 察した.

2.エコーレベルの標準偏差は悪性腫瘍で平 均 8.43 と有意に高く, 良性腫瘍で平均 7.49 , 正 常耳下腺で5.33であった.

3.ヒストグラム幅の検討から, 悪性腫瘍は 裾野・中腹ともに広いベル型, 良性腫瘍は裾野 の広い山型, 正常耳下腺は裙野の狭い山型の 3 つのヒストグラムパターンに分類した.

\section{文献}

1）浅野 尚, 北村 武, 金子敏郎, 他: 耳下腺腫 瘍の超音波診断. 耳鼻臨床 $64: 1263 \sim 1270$, 1971.

2）鈴木晴彦: 超音波診断一理論と応用一. 日耳 鼻 $88: 1502 \sim 1503,1985$.

3）村上 泰 : 耳下腺腫瘍の術前診断. 耳下腺腫瘍 の臨床 第 1 版 (奥田 稔, 他編). 100 103頁, 医学教育出版社, 東京, 1984 .

4）緒方洋一, 野口高昭, 関谷 透: 耳下腺腫瘍の 超音波診断基準の検討. 耳鼻臨床 82 : 1269 1273, 1989.

5）緒方洋一, 関谷 透, 野口高昭, 他 : 頭頸部腫 瘤の内部ェコーヒストグラムの検討. 耳鼻臨床 $83:$ 923 929, 1990.

6) 緒方洋一, 関谷 透, 野口高昭, 他: 頭頸部腫 瘤の内部ェコーヒストグラムの検討 一第 2 報 一. 耳鼻臨床 84 : 803 808, 1991.

$\left(\begin{array}{l}\text { 原稿受付: 平成 } 4 \text { 年 } 3 \text { 月 } 24 \text { 日 } \\ \text { 原稿採択 : 平成 } 4 \text { 年 } 5 \text { 月 } 7 \text { 日 } \\ \text { 別刷請求先 : 緒方洋一 } \\ \text { 干755 宇部市小串 } 1144 \\ \text { 山口大学医学部耳鼻咽喉科学教室 }\end{array}\right)$ 